\title{
Names Shakespeare Didn't Invent: Imogen, Olivia, and Viola Revisited
}

\author{
SARA L. UCKELMAN \\ Durham University, Durham, England
}

Just as Shakespeare's plays left their indelible stamp on the English language, so too did his names influence the naming pool in England at the beginning of the $17^{\text {th }}$ century and beyond. Today, certain popular modern names are often described as inventions of Shakespeare. In this article, we revisit three names which are often listed as coinages of Shakespeare's and show that this received wisdom, though oft-repeated, is in fact incorrect. The three names are Imogen, the heroine of Cymbeline; and Olivia and Viola, the heroines of Twelfth Night. All three of these names pre-date Shakespeare's use. Further, we show in two of the three cases that it is plausible that Shakespeare was familiar with this earlier usage. We conclude by briefly discussing why these names are commonly mistakenly attributed to Shakespeare's imagination; and we examine the weaker, but not mistaken, claims which may underlie these attributions.

KEYWORDS Imogen, literary names, Olivia, Shakespeare, Viola

\section{Introduction}

Shakespeare's plays are well-known for the variety of the characters' names, and the variety of the sources, both linguistic and temporal, that he used. Just as his plays left their indelible stamp on the English language, so too did his names influence the naming pool in England at the beginning of the $17^{\text {th }}$ century and beyond. Many popular modern names are often noted as being inventions of Shakespeare, giving them just that little bit more cachet. In this article, we revisit three names which are commonly listed as coinages of Shakespeare's and show that this received wisdom, though oft-repeated, is in fact incorrect. The three names are Imogen, the heroine of Cymbeline (Shakespeare 1623a; written cr6II); and Olivia and Viola, the heroines of Twelfth Night (Shakespeare I623 b; written cr600-I602). All three of these names pre-date Shakespeare's use. In addition, we demonstrate in two of the three cases that it is likely that Shakespeare was familiar with this earlier usage. 


\section{Imogen}

The current standard explanation for the origin of the name Imogen is that it is a typo-quite literally - for Innogen, in the Folio edition of Shakespeare's play Cymbeline (Hoeniger 1957, I32; Levith 1978; Withycombe 1977, s.n. Imogen). Shakespeare is said to have taken the name, as he did so many others, from Holinshed and Monmouth, where Innogen is the wife of Brute (Brutus), king of Britain. (These are also the sources for Spenser's use of the name, in the spelling Inogene (Boling 2000, 64).) Innogen is mentioned in the first and second chapters of volume 2 of Holinshed's chronicles (Holinshed [I 574] I 587), first when she is proposed to Brute and then after she is married. In Monmouth, Innogen has the distinction of being "the first British proper name in the Historia" (Hutson I940-1944, 8). The name was in use in Brittany in the period running up to Monmouth, with the spellings Ennoguent, Innoguend, and Innoguent found in the Redon cartularies (9th-IIth centuries), and an $\mathrm{II}^{\text {th }}$ century Inoguen in the Histoire de Bretagne (Hutson I940-I944, 8). The origin of Innogen is disputed. Förster (I92I) suggests that it derives from Proto-Celtic *eni-genā, the same root as the root of Old Irish ingen "daughter", but the Breton spellings in -guen(t/d) suggest a connection with Proto-Celtic *windos "white" (mod. Wel. gwyn, gwen) instead.

Coates (I976) disagrees with the "Weekleyan printer's error theory" of the origin of Imogen, arguing that "Shakespeare may have deliberately altered a name ... to suit his purposes" (2). Treating Imogen as a genuine name, he follows Long and states that it is derived "from an unattested Latin *imo(?)gen(a)" (Coates I976, I); however, he differs from Long in suggesting that this compound was intended to mean "lowest-born" rather than "last-born" (Coates I976, 2).

It is not our point here to settle the issue of whether Shakespeare's Imogen was merely a typo or a deliberate alteration of Holinshed. Instead, the primary contribution of this paper is to draw attention to a hitherto unknown or overlooked pre-Shakesperean example of the name. ${ }^{\mathrm{I}}$ In a Latin charter dated 5 January I256, Werner IV von Bollanden waived his rights to his lands in Udenhusen, Richartshusen, Nuendorf, and Berghusen, and "hoc facimus favore uxoris nostre Imogenis" - "This we do with the approval of our wife Imogenis' (De Gudenis I 768,887 , no. XXI). If this citation is reliable, it represents a genuine example of the name Imogen some three and a half centuries before Shakespeare.

There is some uncertainty concerning the reliability of this citation. Gudenus's transcription has a marginal note informing us that his reading of Imogenis is "indubie corrupt" ("undoubtedly corrupted"). ${ }^{2}$ Such a comment immediately indicates that personally viewing the original manuscript is advised. Unfortunately, Gudenus gives no information about the provenance of his source, nor would it be any easy task to follow the manuscript forward in time 250 years to locate it today, if it still exists. So in order to determine the 
likelihood that Gudenus's transcription is "undoubtedly corrupted", one must consider what Imogenis could be a corruption or misreading of.

This question would easily be answered by an independent reference to the same person. Werner's wife was the daughter of Konrad von Merenberg and his wife Guda. A number of $18^{\text {th }}$ and $19^{\text {th }}$ century German sources ${ }^{3}$ call their daughter Imagina, a name for which many other $13^{\text {th }}$ century examples can be found. ${ }^{4}$ However, we have yet to find any contemporary record which refers to her as Imagina. It may be that modern historians, following Gudenus's uncertainty concerning Imogenis, misidentified her name as Imagina on the basis of the other $\mathrm{I} 3^{\text {th }}$ century examples, without any positive evidence that she was in fact called this contemporarily.

One reference to this wife of Werner's (his second), in an unreliable, nonscholarly website that cites no sources (Schommer 20I6), calls her Irmagenis. We have found no evidence to corroborate this, and thus this example must be treated with caution, if not discarded outright. Further, we have been unable to find any independent examples of Irmagenis, leading us to doubt the existence of such a name. The name itself is not especially plausible as a constructed Germanic name. Irma- or Imm[o/a]- is a hypocoristic of Old High German ermen, Old Saxon irmin "strong" found both as a prototheme and as a monothematic name in France and Germany in the $7^{\text {th }}-\mathrm{II}^{\text {th }}$ centuries (Morlet I97I, $84 \mathrm{~b}-85 \mathrm{a}$; Uckelman and Uckelman $20 \mathrm{I} 7 \mathrm{~b}$ ). But while the prototheme is well established, the deuterotheme, -genis, is problematic. No other Germanic names using this theme have been found, and dithematic names combining Old German and Latin elements are rare, and no other more plausible origin presents itself.

Another possibility is that Imogenis is a misreading or a miswriting of Innogenis, just as Imogen is (purportedly) a misspelling of Innogen. ${ }^{5}$ This is unlikely. First, none of the Breton examples of the name spell the deuterotheme in this way. Second, the cultural context of the citation makes it unlikely, for it is implausible for this Celtic name to have occurred in Germany in the middle of the $\mathrm{I} 3^{\text {th }}$ century.

Lacking independent evidence that Werner's wife was called Imagina, and lacking another plausible alternative candidate name, the most likely explanation is that the form Imogenis is genuine, and that Gudenus's skepticism is misplaced.

\section{Olivia}

The second name commonly, and incorrectly, noted as an invention of Shakespeare that we consider is Olivia (Hough 2000, 5). Here, our evidence is much less controversial and more definitive than our evidence for Imogen. The name Olivia occurs in Latinized English contexts as early as the late $\mathrm{I} 3^{\text {th }}$ century, as a variant of Oliva (Uckelman 20I7a). That Oliva and Olivia are variants of each other is demonstrated by records showing the same person known 
by both forms. For example, a record from I 296 refers to both "Elizabetham filiam et heredem Olive de Gurneye" ("Elizabeth daughter and heir of Olive de Gurneye") and "eadem Olivia mater ipsius Elizabeth" ("the same Olive mother of Elizabeth herself") (Anonymous I 805, 95b). Another example of the spelling Olivia occurs in I32I. The interchanging of $-a$ and $-i a$ in Latinized forms of English feminine names can be found in other names, for example, Sibilia/Sibilla, Amabilia/Amabilla, Mabilia/Mabilla, and Cecilia/Cicilla, all found in I38I (Le Get et al. 20I7; Uckelman and Uckelman 20I7a; Uckelman 20I7b).

Variants of this Oliv(i)a were, not surprisingly, also used in France, Italy, and Spain, and the vernacular form Olive was not uncommon in England in the I6th century (Uckelman 20I7a). There is no reason to think that this name would have been unfamiliar to Shakespeare, or that using Olivia as opposed to Oliva as the Latinate/Italianate form of the name would have been considered unusual.

\section{Viola}

The third name often cited as being invented by Shakespeare that we consider is Viola. Law argues that Twelfth Night's Viola derives from removing the letters "sil" from Silvio-Silla, the pair of names (masc./fem.) used by the character's counterpart in Barnabe Riche's Farewell to Militarie Profession, and includes Viola as an example of "names ... I take as invented by Shakespeare' (Law I95I, 65). But this postulates invention where none is needed. The name Viola, deriving from the Latin word viola "violet", was already in use in Italy, Hungary, and Ukraine (Uckelman 20I7c). Other words for this plant also gave rise to given names used throughout Europe. The Greek root $10 \lambda \alpha \nu \theta 0$, "violet flower" gave rise to the names Yolanda and Violante that were found in France, Hungary, Italy, and Spain from the late $13^{\text {th }}$ century (Slíz et al. 20I7). There is also the name Violet or Wyolet which is identical to the name of the flower and is derived from an Old French diminutive of the Latin word. This name was moderately popular in the $16^{\text {th }}$ century in Scotland due to the influence of the name in France at the same time (Uckelman 20I7d). Thus, Shakespeare's use of the name follows his established pattern of co-opting Italian or Latin names.

\section{Conclusion}

We have considered three names commonly cited as being inventions of Shakespeare, Imogen, Viola, and Olivia. We have shown that latter two certainly pre-date Shakespeare and that the first likely does, though our evidence is not definitive. What this evidence demonstrates is that one must treat statements that a certain name was invented by a certain august literary figure for a certain literary application with some caution, for they may not always be true. One reason that these statements might be false but commonly repeated is that they are being used as proxies for different statements which are true: for example, 
(a) that the author thought he or she was coining a name; (b) that the use of a particular name in an important literary source is the cause of the name's later popularity; or (c) that the use of a particular name in a particular linguistic context is due to a particular author's use of the name. The three names that we have considered here illustrate each of these three possibilities.

With respect to Imogen, it is important to stress that we are not arguing that Shakespeare was familiar with an obscure $\mathrm{I} 3^{\text {th }}$ century German charter, or even with the person referred to in the charter. There is no reason to think that his inspiration for the name was anything other than Holinshed and Monmouth. If he did indeed deliberately change Innogen to Imogen, then he likely thought he was coining a new name by doing so.

On the other hand, given the common currency of Viola and Olivia and related forms of these names, it is plausible that Shakespeare was familiar with these names and did not think of himself as inventing them for this play. However, it is clear that his choice to use these names had repercussions for the future use of the names outside of literature. With respect to Olivia, there is no reason to doubt the claim that the name's enduring popularity in English-speaking contexts is due to Shakespeare (Withycombe I977, s.n. Olivia), while Viola does have some genuine claim to being an invention of Shakespeare in a limited sense. While Viola was already in use as a name before Shakespeare, we don't yet have any evidence that the name was used in England. Thus, it certainly counts as a novel import, and so in this respect it is correct to say that Shakespeare invented Viola as an English name.

\section{Notes}

I. Thus contradicting Coates (I976), "The female personal name Imogen is first recorded as the name of the heroine of Shakespeare's Cymbeline" (I).

2. The charter is reprinted, without the marginal note, in Hennes I845, I49, no. I 58 . A portion of it is reprinted in Grusners $\mathrm{I} 775,62$, with the relevant text reading "Et hoc facimus favore Vxoris nostre Imoginis", which introduces its own typo!

3. For example, Grusners I775, 63; Heyer I 828, 27; von Reisach and Linde I835, 4; and others.

4. In the second half of the $\mathrm{I} 3^{\text {th }}$ century, both the wife of Gerlach, Count of Limburg, and one of his daughters, who was later married to Adolf, Count of Nassau, were named Imagina. The daughter is named as Imagina in 1279 (Anonymous I830, I04-I06, nos I, 2), while her mother (daughter of Heinrich, Count of Blieskastel), and Agnes von Sayn, are recorded as Ymagina in 1266 (Lacomblet I 846, 329, no. 565). Adolf also apparently had a sister named Imagina (von Behr I 870, 98, table XCVIII). These are not the only instances that can be found in $13^{\text {th }}$ century German or Netherlandish contexts.

5. Though Innogenis is more likely to be misread as Irmagenis or Irmogenis than Imogenis, since "nn" and "rm" share the same number of vertical strokes, while " $\mathrm{m}$ " has one fewer.

\section{Disclosure statement}

No potential conflict of interest was reported by the authors. 


\section{Bibliography}

Anonymous. I805. Rotulorum Originalum in Curia Scaccarii Abbreviatio, Vol. I: Temporibus Regum Hen. III, Ed. I, and Ed. II (Printed by Command of His Majesty King George III).

Anonymous. I830. Annalen des Vereins für Nassauische Alterthumskunde und Geschichtsforschung, Vol. I. Wiesbaden: Rosten des Bereins.

Boling, Ronald J. 2000. "Anglo-Welsh relations in Cymbeline”. Shakespeare Quarterly 5I, no. I: 33-66.

Coates, Richard A. I976. "A personal name etymology and a Shakespearean dramatic motiv". Names 24, no. I: I-8.

De Gudenus, Valentinus Ferdinandus, ed. I768. Codex Diplomaticus Anecdotorum Res Moguntinas, Francicas, Trevirenses, Hassiacas, Finitmarumque Regionum ..., Vol. 4. Frankfurt: Ioan. Christoph. Stoehr.

Förster, M. I92I. Keltisches Wortgut im Englischen. Halle: Niemeyer.

Grusners, Johann Adam, ed. I775. Diplomatisches Beytrage, Vol. I. Frankfurt in der Andreaischen Buchhandlung.

Hennes, Johann Heinrich, ed. I 845. Urkundenbuch des Deutschen Ordens, Vol. I. Codex Diplomaticus Ordinis Sanctae Mariae Theutonicorum. Mainz: Franz Kirchheim.

Heyer, S.F. 1828. Ueber die sponheimische Surrogat- und Successionsfrage: Eine kritische Beleuchtung der Schrift. Tubingen: In der J.S. Gotta'schen Buchhandlung.

Hoeniger, F.D. I957. “Two notes on Cymbeline”. Shakespeare Quarterly 8, no. I: I32-3.

Hough, Carole. 2000. "Towards an explanation of phonetic differentiation in masculine and feminine personal names". Journal of Linguistics 36, no. I: I-I I.

Lacomblet, T.J., ed. I846. Urkundenbuch für die Geschichte des Niederrheins, Vol. II. Düsseldorf.

Law, Robert Adger. I95I. On Certain Proper Names in Shakespeare. In University of Texas Studies in English 30, no. I95 I: 6I-5.

Le Get, R., N. Shiel, J. Uckelman, and S.L. Uckelman. 20I7. Cecilia. In The Dictionary of Medieval Names from European Sources, Edition 20I7, No. I, ed. S.L. Uckelman. <http://dmnes.org/20I7/I/name/ Cecilia $>$.

Levith, Murray. 1978. What's in Shakespeare's Names. Hamdenn, Conn: Archon Books.

Holinshed, Raphaell, William Harrison, Iohn Hooker, et al. [I 574]I587. The First and Second Volumes of Chronicles: Comprising I. The Description and Historie of England, 2. The Description and Historie of Ireland, 3. The Description and Historie of Scotland.

Hutson, Arthur E. I940-1944. British Personal Names in the Historia Regum Britanniae. Berkeley, CA: University of California Press.

Morlet, Marie-Thérèse. I97I. Les Noms de Personne sur le Territoire de l'Ancienne Gaule du VIe au XIIe Siècle, Vol. I. Paris: Centre National de la Recherche Scientifique.

Schommer, Andreas. “v. Bolanden,” < http://andreasschommer.gmxhome.de/html/v__bolanden.html > (accessed 7 September, 2016).

Shakespeare, William. I623a. The Tragedie of Cymbeline. In Mr. William Shakespeare's Comedies, Histories, \& Tragedies. London: Isaac Jaggard and Edward Blount.

Shakespeare, William. I623b. Twelfe Night, or what you will. In Mr. William Shakespeare's Comedies, Histories, \& Tragedies. London: Isaac Jaggard and Edward Blount.

Slíz, M., J. Uckelman, and S.L. Uckelman. 20I7. Yolanda. In The Dictionary of Medieval Names from European Sources, Edition 2017, No. I, ed. S.L. Uckelman $<$ http://dmnes.org/20I7/I/name/Yolanda $>$.

Uckelman, J., and S.L. Uckelman. 20I7a. Amabel. In The Dictionary of Medieval Names from European Sources, Edition 2017, No. I, ed. S.L. Uckelman. <http://dmnes.org/20I7/I/name/Amabel>.

Uckelman, J., and S.L. Uckelman. 20I7b. Emma. In The Dictionary of Medieval Names from European Sources, Edition 20I7, No. I, ed. S.L. Uckelman. <http://dmnes.org/20I $/ / \mathrm{I} / \mathrm{name} / \mathrm{Emma}>$.

Uckelman, S.L. 20I7a. Olive. In The Dictionary of Medieval Names from European Sources, Edition 20I7, No. I, ed. S.L. Uckelman. <http://dmnes.org/20I $7 / \mathrm{I} /$ name/Olive $>$.

Uckelman, S.L. 20I7b. Sibyl. In The Dictionary of Medieval Names from European Sources, Edition 2017 , No. I, ed. S.L. Uckelman. <http://dmnes.org/20I $7 /$ I/name/Sibyl $>$.

Uckelman, S.L. 20I7c. Viola. In The Dictionary of Medieval Names from European Sources, Edition 20I7, No. I, ed. S.L. Uckelman. <http://dmnes.org/2017/I/name/Viola $>$.

Uckelman, S.L. 2017 d. Violet. In The Dictionary of Medieval Names from European Sources, Edition 20I7, No. I, ed. S.L. Uckelman. <http://dmnes.org/20I7/I/name/Violet>.

von Behr, Kamill. I870. Genealogie der in Europa regierenden Fürstenhäuser. Leipzig: Bernhard Tauchnitz. 
von Reisach, Karl-August, and Peter Adolph Linde. I835. Archiv fur Rheinische Geschichte, Vol. I. Coblenz: im Berlage bei Hölscher.

Withycombe, E.G. I977. The Oxford Dictionary of English Christian Names, 3 rd edtion. Oxford: Oxford University Press.

\section{Notes on contributor}

Sara L. Uckelman works at Durham University and is the editor-in-chief of the Dictionary of Medieval Names from European Sources. Her interests include the personal and place names of pre-I600 Europe, as well the effects of medieval naming practices on contemporary fantasy fiction.

Correspondence to: Dr. Sara L. Uckelman, Durham University, 50 Old Elvet, Durham DHг 3 HN, England. Email: s.l.uckelman@durham.ac.uk 